\title{
Estimating long term sediment yields from sediment core analysis
}

\author{
PATRICIA KENNIE, JIM BOGEN, HANS CHRISTIAN OLSEN \\ Norwegian Water Resources and Energy Directorate
}

\begin{abstract}
Estimating long term sediment yields from sediment core analysis. Sediment cores from lakes and reservoirs can be used to estimate sediment yields. In proglacial lakes, the bed sediment typically accumulates as varves, reflecting changes in seasonal and annual sedimentation. This report compares the results from two different methods of measuring suspended sediment transport in a Norwegian glacial river and lake. Sediment yields obtained from a study of sediment cores in the proglacial lake Nigardsvatn along with measurements of the delta topset were compared with a 25-year record of sediment transport based on automatic water sampling and water discharge measurements at a monitoring station at the inflowing river. During the period from 1980 to 2005 , analyses of sediment cores taken from the lake bed along with measurements and grain size distribution analysis of the delta indicated that a volume of 175,670 to $202,697 \mathrm{~m}^{3}$ was deposited in the lake Nigardsvatn and corresponding river delta. The year 1980 was selected as a convenient starting point because a large-magnitude flood with a 100-year recurrence interval occurred at the end of 1979, leaving an easily recognizable sediment layer and accurate reference point. Sediment cores were taken at a total of 24 locations throughout the lake and 25 locations in the delta. The densities of the sediment cores were found to vary between 1.3 and $1.5 \mathrm{~g} / \mathrm{cm}^{3}$ during the period examined in this study, giving a total suspended sediment load of between 175,670 and 202,697 tons. The measurements carried out at the sediment station in the glacier melt-water river gave a value of 294,800 tons during the same period. A final value of 211,100 tons is calculated from the monitoring station results after deduction of the sediment fraction which passes through the lake without being deposited. This gives a discrepancy between the two methods of 8,403 to 35,430 tons
\end{abstract}

(4-20\%). This can be partially attributed to the difficulties of measuring the water discharge in the unstable glacier meltwater river. In conclusion, sediment cores may be used to extrapolate or correct measurements from sediment monitoring stations over longer periods but caution should be made when considering single years.

Key words: glacial river, Nigardsvatn lake, sediment transport.

\section{INTRODUCTION}

This paper examines the relation between sediment transport in a glacier fed river and sedimentation in a proglacial lake in western Norway. Two methods of measuring annual suspended sediment transport and deposition are: the routine sampling of water from rivers and analysis of sediment cores from lake bottoms. Many individuals and institutions have used one or both of these two methods to estimate annual sediment yield (Bogen and Bønsnes 2003; Gilbert et al. 2005; Zolitschka 1998). However, there has been very little research done which directly compares the results of these two methods. The following report is a discussion of the results from an intensive research project conducted by the Norwegian Water Resources and Energy Directorate (NVE) over 25 years in the meltwater river and lake from the Nigardsbreen glacier. This is an outlet glacier from the Jostedalsbreen 
ice cap in western Norway. The catchment area is covered by ingenous and metamorphic rocks. Important minerals are mica, feldspar and quartz (Olson and Ziegler 1987). The total suspended sediment load which settled from 1980-2005 was calculated from a combination of sediment cores taken in the lake bottom and the results of measurements of the volume of suspended materials accumulated in the delta during this period. These results were compared to the 25-year record of suspended sediment transport from routine water sampling in the glacial river. The anticipation was that the results from these two methods would be similar enough that sediment core analysis could be used to extrapolate suspended sediment yield for longer periods where water sampling has not been taken, or to correct for inaccurate results.

\section{MATERIALS AND METHODS}

\section{Sediment sampling in the glacial river}

From 1967 to 1978, suspended sediment yield was measured through manual sampling, both at the inlet and outlet of Nigardsvatn lake. In 1978, sample taking was ceased at the outlet of the lake, and from 1978 to 1981 suspended sediment yield was calculated from samples taken manually at the lake inlet. In 1982 a sediment monitoring station was established.

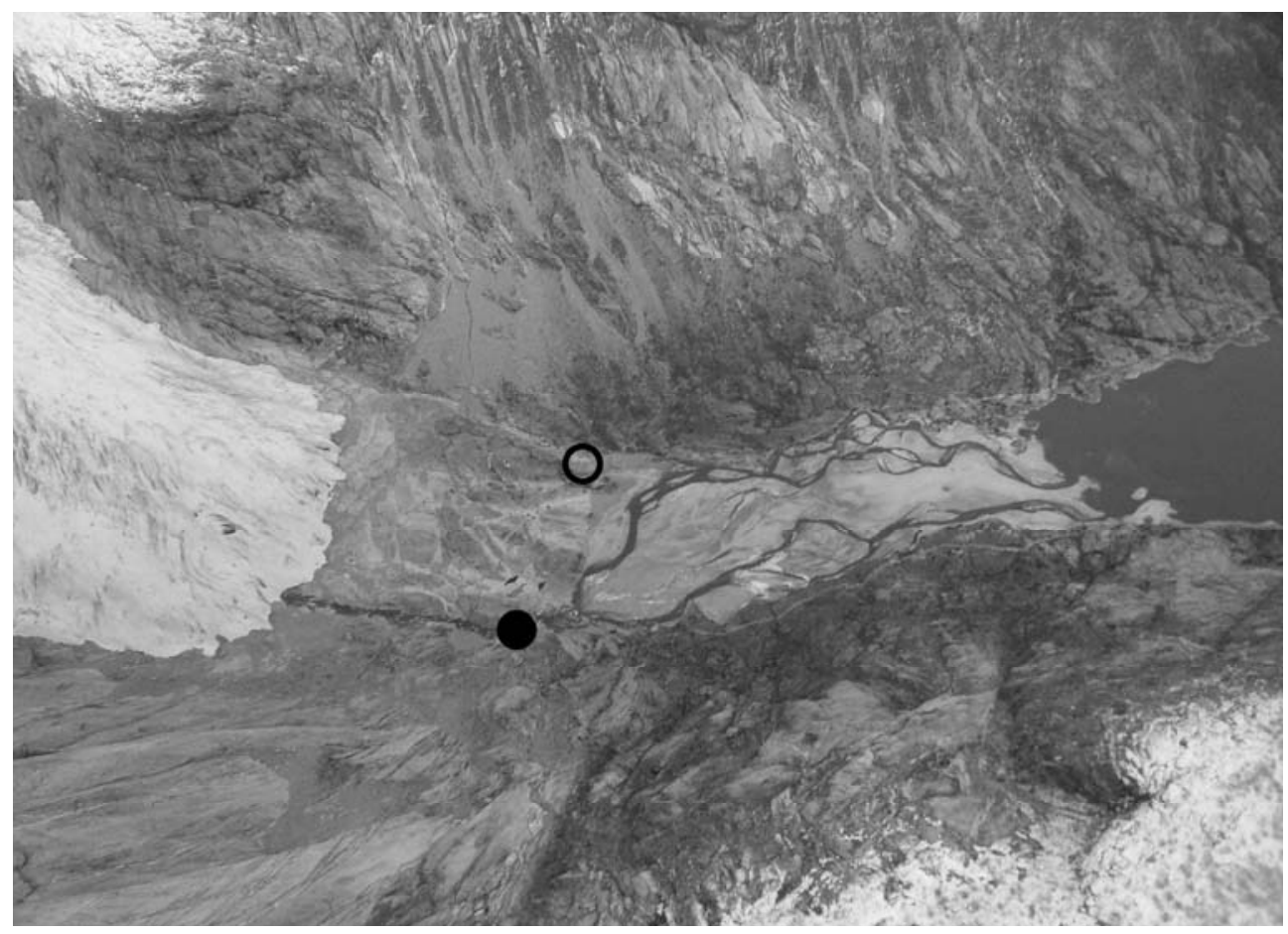

FIGURE 1. Nigardsbreen glacier and Nigardsvatn lake and delta topset. The solid circle indicates the position of the main ISCO sediment monitoring station and the ring indicates the location where the supplementary station was placed for the second river channel after the glacial advance of 1999-2006 
This involved an ISCO programmable automatic water sampling machine set inside a small cabin which was built beside the glacial meltwater river flowing from Nigardsbreen glacier to Nigardsvatn lake. In 1999, the melt water was split into two main rivers emerging from the glacier, due to the changes in the glacial front caused by a glacier advance. To obtain data from both of the rivers an extra sediment monitoring station was established in 2000. The location of the monitoring stations can be seen in Figure 1. The official procedure used by NVE for sampling suspended particles in rivers is described in detail by Bogen (1986). The samples were taken two to four times per day over this whole period. After the samples are filtered, dried and weighed in the laboratory, annual sediment transport is calculated from the volumes of each sample and data on water levels and water discharge which are also collected by NVE.

\section{Sediment cores from Nigardsvatn lake bottom}

Sediment cores were taken from the bottom of the lake on several occasions beginning in 1952, but this study uses the results from sediment cores taken in 2006. These cores were taken on this occasion from 24 locations at the lake bottom to analyse suspended sediment transport. The locations in the lake of which the cores were taken from can be seen in Figure 2. All cores were taken from the ice platform in April of 2006 except for those at locations $\varnothing, \AA, \mathrm{O}-2$ and $\mathrm{N}$ which were taken in August of 2006 from a raft, due to thin ice in April of that year. A percussion corer was used for all of these samples. This type of sediment sampler has been used by Reasoner (1993) and Gilbert (1985) and has been described as a relatively lightweight corer which consists of a hollow tube with a weight, stand and pulleys and

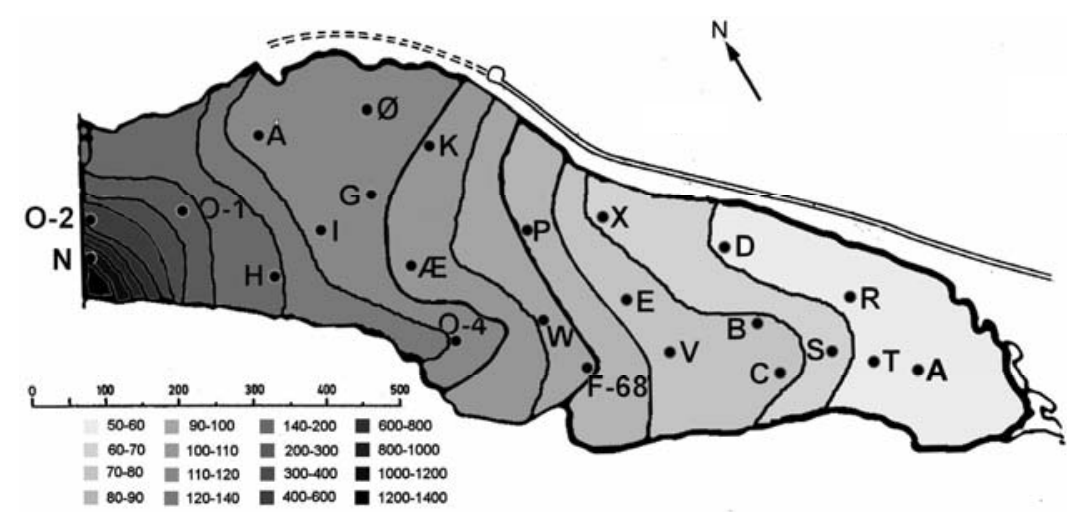

FIGURE 2. Map of bed sediments in lake Nigardsvatn. The black circles and letters show each location where a sediment core was taken. The segments show the areas used to calculate total sediment accumulation. Grey colours indicate the thickness of total suspended sediment accumulation from 1980-2005 in mm within each segment 
is operated from a surface of stable ice. After a hole is made through the lake ice, the corer is slowly lowered down through the water and driven into the bottom sediments with a weighted driver or hammer attached to pulleys. Cores are then retrieved by a pulley system anchored to the pack-ice.

On August 14th 1979 a large magnitude flood occurred due to torrential rains, which has been described by Bogen (2006) as well as Gjessing and Wold (1980). The layer deposited during this flood is clearly visible in the sediment cores and was used as a reference layer. In addition, red brick powder was deposited in Nigardsvann in 1968 and 1980 and this layer was visible in several of the samples providing 1968 as another accurate point of reference. The sediment cores, like the suspended sediment samples, were all analysed by the NVE hydrological laboratory in Oslo. Sedimentation over the period of one year is deposited as "varves" consisting of a summer and a winter layer. The winter layer is much thinner and darker than the summer layer due to the lesser amount of organic material as well as the longer settling time because of the decreased water flow rate in the winter months (Gustavson 1972). The clearly visible varves could therefore theoretically provide a measurable source of data for estimating and comparing annual sediment transport and sedimentation. After the sediment cores are sawed in two and the surfaces are prepared, the cores were photographed under different light and moisture conditions. The best pictures were then selected for analysis. Cores A, B1, C, D, F, G, I, R, S, W, and X2 had the best layers and the thickness of each layer from 1979-1980 could be seen, therefore these could be fully analysed. Cores $\mathrm{H}$ and $\mathrm{P}$ could only be analysed for the entire thickness from 1979 to 2005 but not for each individual year in between. The other cores could not be used for this project due to unclear or distorted varves, and several of the locations closest to the delta had such a large amount of sedimentation that the cores were only long enough to show the top few years. The photographs of the forenamed cores were analysed using JPEG Editor, a computer program which first differentiates between each summer and winter varve by measuring darker and lighter pixels. Some of the pictures had to be slightly corrected using the Paintshop program, due to the presence of pseudovarves and lighter winter varves which were not easily detected. These files were then run through another feature of the same program which calculates the thickness of each annual sedimentary layer for each individual core. Figure 3 shows a core which has been analysed with this program. A map of the total sedimentation area of the lake basin was then separated into arbitrary bisections of known area, which were allocated with regards to distance from the river and placement of cores with similar profiles (Fig. 2). The average sediment core varve thickness for the period 1980-2005 within each cross section could then be multiplied by the section's area to obtain the total sediment volume of the section in $\mathrm{m}^{3}$. There were several areas with no cores or unusable cores, especially those bordering the delta. The results were extrapolated for these areas from the volumes calculated from both the lake and delta sections. Using the results obtained from 


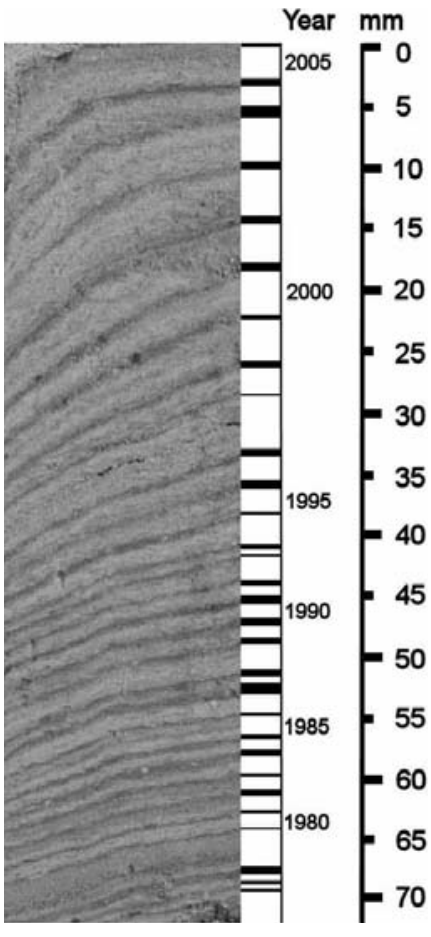

FIGURE 3. Sediment core "S" and results of the JPEG editor program analysis. The annual varves are clearly visible and the black-and-white strip shows the summer (white) and winter (black) layers. The scale shows the thickness in $\mathrm{mm}$

the sediment core density analysis (1.3 to $1.5 \mathrm{~g} / \mathrm{m}^{3}$ ) the total sediment yield was calculated in tons.

\section{Suspended sediments deposited in the delta topset}

NVE has been measuring the annual sedimentation in Nigardsvatn delta since 1968, using surveying equipment. The procedure for measuring delta growth is described by Østrem et al. (2005); NVE has fastened bolts into the mountains in 21 locations on both sides of the glacial valley, and stretches a wire cable across pairs of these bolts in a total of 38 to 41 combinations. The elevation of the delta was measured along each wire at 5-meter intervals, giving a total of approximately 1000 single measurements. The total sediment accumulation over the year can then be calculated using this data along with the measurements from the previous years.

Suspended sediments are deposited in the delta topset amongst a large amount of coarse material and therefore do not settle here as varves. The limit for suspended sediment here was assigned as material under $0.5 \mathrm{~mm}$, particles with a larger size than this are transported by bed load processes. The majority of the material deposited in the delta is over $0.5 \mathrm{~mm}$ and therefore bed load, moved in contact with the river bottom. It was previously thought the amount of suspended sediments deposited in the delta was negligible as the majority was believed to be carried out to the lake, but the studies of NVE have shown quite the contrary, with the delta topset proving to be an important sedimentary sink for suspended sediments. In order to determine the amount of suspended sediments deposited in the delta, sediment cores were taken at 25 locations evenly distributed throughout the area of the delta, to a depth of 15-20 $\mathrm{cm}$ deep. Since the delta has too much coarse material and therefore does not settle as varves, another analysis technique was used. These core samples were analysed for grain size distribution to determine the percentage of which was in the suspended fraction at each location. The delta was then divided into sections with known area on the basis of similar grain size distribution profiles and bottom topography. The grain size distribution results along with those from the measurements of annual delta growth were 


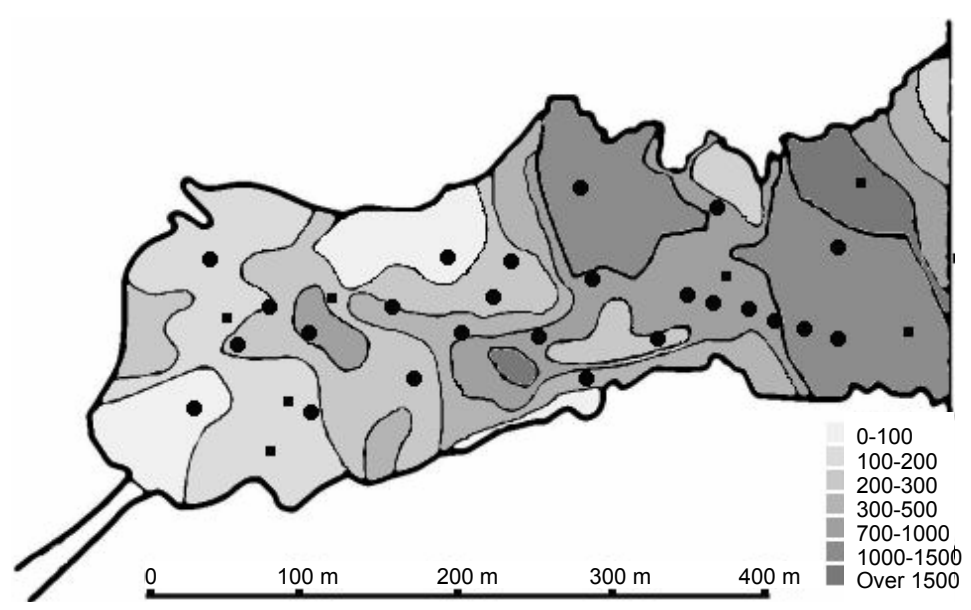

FIGURE 4. Map of delta topset in lake Nigardsvatn. The square dots show the locations where samples were taken for grain size distribution analysis in 1983 and the circular dots show the points where samples were taken in 2007. This map shows how the delta was segmented into areas for calculation of total suspended sediment load and each grey colour represents the total accumulation of sediments in the suspended fraction in $\mathrm{mm}$ (material under $0.5 \mathrm{~mm}$ ), from 1980 to 2005

used to calculate the total amount of suspended sediments deposited in each area. Figure 4 shows a map of the delta topset and the locations of each sediment core used for grain-size distribution, as well as the divisions between each section which was used in the calculations, based on amount of suspended sediment accumulated. The volume results from each area were then added together to obtain the total volume of sedimentation in the suspended fraction deposited in the delta from 1980-2005.

\section{RESULTS}

\section{Sediment monitoring station results}

From the analyses of the water samples taken over this 25 -year period at the sediment monitoring stations, 294,800 tons of suspended sediments were transported into Nigardsvatn during this time. $75 \%$ of the total suspended sediment load is considered to have settled in the lake, as approximately $25 \%$ passes through the lake. These values were determined by the study period when NVE took samples at both the inlet and outlet of Nigardsvatn. After correcting for the sediment fraction which passes through the lake without settling, a final value of 211,100 tons is calculated for the total suspended sediment load from 1980-2005 which would accumulate in the lake. Figure 5B shows a graph of annual sediment transport from 1979 to 2005 as measured by the sediment monitoring station, as well as annual runoff during this period.

\section{Lake sediment core results}

The total volume of $49,769 \mathrm{~m}^{3}$ of sediments was deposited in Nigardsvatn lake bottomset during the period from 1980 to 2005. Density was also calculated from many of the sediment core samples, giving values of between 1.3 and $1.5 \mathrm{~g} / \mathrm{cm}^{2}$. 
After calculating total weight of sedimentation using each of these two values, a total mass of 64,700 and 74,654 tons was found.
The majority of the material in the sediment cores, $80-90 \%$ was determined to be silt, ranging in particle size from 2 to $63 \mu \mathrm{m}$. Only $3-7 \%$ was found to be

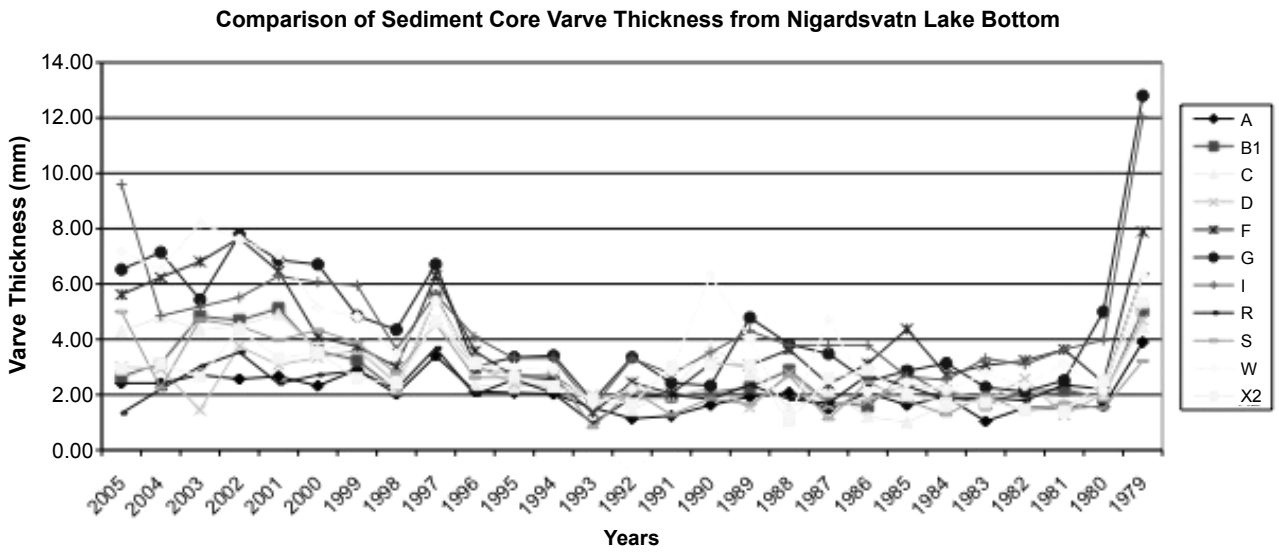

FIGURE 5A. Graph of sediment core varve thicknesses from Nigardsvatn lake. This graph shows how each annual varve compares with those of the other cores

Annual Suspended Load vs. Annual Runoff

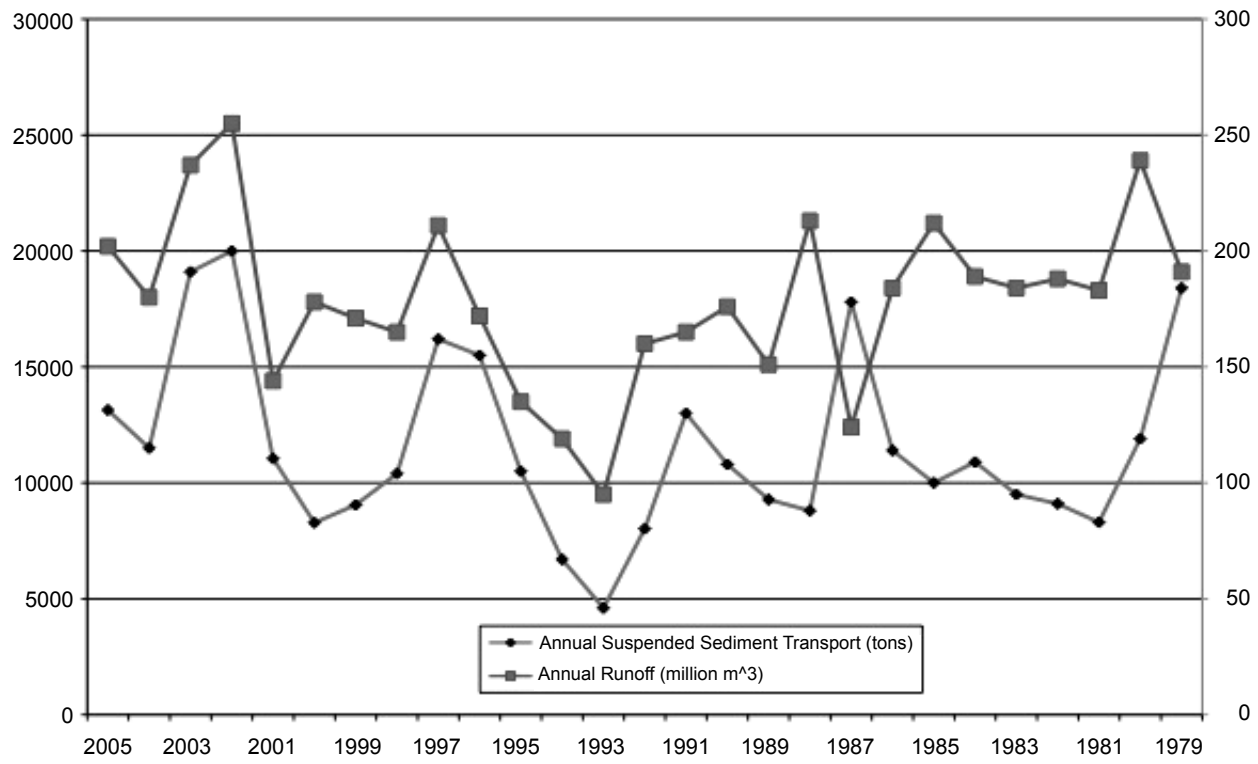

FIGURE 5B. Graph of annual sediment transport vs. annual runoff. The values for the sediment transport in tons are on the left and the values for the annual runoff in milliong of cubic meters are on the right 
in the clay fraction (under $2 \mu \mathrm{m}$ ). Under $10 \%$ was in the sand fraction $(63 \mu \mathrm{m}$ to $2 \mathrm{~mm}$ ). These particle size distribution analyses found also that particle size decreases with distance from the delta, and that gravel was found only in the part of the lake nearest to the delta foreset.

It was also found that the average annual varve thickness varied exponentially with position in the lake. The cores taken closer to the inlet had thicker layers than the cores taken closer to the lake outlet (Figs 3 and 5A). This same result was also found by Bogen (1983). In addition, the core taken furthest from the lake inlet, at position $\mathrm{A}$, had little difference in thickness of each annual varve, with the exception of the 1979 and 1997 which were quite a bit thicker due to extreme flood events (Fig. 5A). This is probably due to the fact that the current is stronger at the inlet of the lake and becomes weaker with distance away from the glacial river, decreasing the suspended sediment carrying capacity of the water. Furthermore, a large amount of the sediments are deposited closer in to the delta, before the stream reaches the outermost reaches of the lake.

\section{Delta topset measurements}

The amount of material in the cores taken from the delta which was in the suspended fraction varied from $6-7 \%$ in the samples taken closest to the glacier, to $80-90 \%$ at the delta front, with an average of $42.6 \%$. The calculations of the volume of suspended sediments deposited in the delta using the combination of surveying measurements and grain size analysis showed a total volume of $85,362 \mathrm{~m}^{3}$ was deposited on the delta topset from 1980-2005. Using the same values for density, 1.3 and $1.5 \mathrm{~g} / \mathrm{cm}^{2}$, a total weight of between 110,971 and 128,043 tons is obtained.

\section{Comparison of methods}

When the results of the calculations for the lake bottom sediment cores and the delta measurements are added together, a total volume of $135,131 \mathrm{~m}^{3}$ is found. The total weight of all sediments in the suspended fraction which accumulated in the entire lake and delta area during this period is then calculated as 175,670 to 202,697 tons, depending on density. When these results are compared against those from the sediment station water samples $(211,100$ tons), the difference is 8,403 to 35,430 tons ( $4 \%$ to $20 \%$ ), depending on whether a value of 1.5 or 1.3 $\mathrm{g} / \mathrm{cm}^{2}$ is used for the sediment density on the lake bottom and delta topset. These results show that $63 \%$ of the suspended sediments are deposited in the delta topset while $37 \%$ are deposited on the lake bottomset.

\section{DISCUSSION}

The results show a fairly good correlation between the two methods of measuring annual sediment transport; water sampling and sediment cores if we consider the time period of 25 years. A difference of $4 \%$ to $20 \%$, depending on sediment core density, is relatively small. This corresponds to an excess of 8,403 to 35,430 tons measured from the water samples from this period which are not reflected in the sediment cores. This difference can be accounted for by some of the impeding factors which arose during the study period to interfere with the obtainment of accurate results 
from both methods. These factors are discussed below.

\section{Inaccuracies in measuring water discharge}

Water discharge measurements in the glacier meltwater river involve large problems. The bedload supplied from the glacier caused severe changes in the controlling profiles of the water stagewater discharge curve. The river flow on the reach from the glacier front and down to the lake is very turbulent and channel shape is irregular. In addition, snow avalanches from the western side of the valley influence the river flow. Thus, water discharge at the lake outlet has often been used as the basis for the calculation of sediment yield. This will give results of higher water discharge and therefore higher values of annual sediment transport. Another important factor influencing discharge measurements is the oscillations of the glacier front.

In 1996 a glacial advance brought about major changes in the sub-glacial channel system at the glacier front. In May of 1998, only one main channel of glacial melt water was observed, but sometime between this point and 1999 the glacial meltwater river split in several channels. From 1999 to 2006 there were two main channels, and in periods up to four channels were observed and parts of the runoff did not drain in channels, and spread out over the bedrock in the glacier forefield instead. This made obtaining an accurate estimate of total water discharge and suspended load extremely difficult, causing the sediment measurements to be very inaccurate during this period. Due to these channel changes, water discharge was measured at the outlet of the lake instead of at the inlet with the monitoring station. This is thought to give larger measurements than usual, as precipitation into the lake would cause a greater volume of water to flow out, leading to higher measurements of discharge and subsequently high values for sediment transport.

\section{Sedimentation on the delta topset}

The delta topset can act as a source or sink for suspended sediments in different years, depending on hydrological conditions. Most material deposited in the delta is over $5 \mathrm{~mm}$ and is deposited by bed-load transport processes. Approximately $42.6 \%$ of the delta topset is suspended material, but this value varies from $6 \%$ to $90 \%$ with proximity to the glacial river inlet. Since there was a lot of variation in the grain size analyses of the 25 samples taken from the delta, more samples would probably give a more accurate result for total amount of deposited suspended sediments. In addition, there should theoretically be significant variation in the proportion of total suspended sediment load which is deposited in the delta in different years due to fluctuating water levels, discharge and channel changes. Since it was not possible to measure the proportion of suspended sediments deposited each year, the same percentage was used to calculate the total amount over the 25-year period for each segment area. Channel changes and fluctuating water discharges can lead to varying degrees of erosion or sedimentation in the delta, which will in turn cause respectively thicker or thinner varves in the lake bed. This will influence the relation between varve thickness and measured sediment transport. Years with significant erosion 
of the delta will cause a greater amount of sediments to settle in the lake, giving thicker varves in the lake bottom and higher values from the sediment core analysis. On the other hand, years with more deposition of suspended sediments in the delta will cause the opposite effect, thinner varves in the lake and the appearance of less sediment transport from the glacier. The year 1987 for example had an unusually large value for suspended sediment transport as measured from the monitoring station, yet this value was not reflected in the varves of the sediment cores. A possible reason for this is that this year saw a much larger accumulation of suspended sediments in the delta topset than in the lake bottom.

\section{Uncertainty of density estimation}

Other sources of error include the estimation of density, as this was measured using small volumes and varied with location, giving results from 1.3 to $1.5 \mathrm{~g} / \mathrm{cm}^{2}$. There is also evidence that the density varies with depth, and the lower, earlier layers are packed down and spread out over time (Olson and Ziegler 1987).

\section{Fraction of sediments passing through Nigardsvatn}

The value of $25 \%$ which was used for the amount of sediments melting from the glacier which pass through Nigardsvatn to the outlet river was calculated from old measurements. The period in which sampling of suspended sediments was done at both the lake inlet and outlet was from 1967-1978, and therefore the results could be outdated. The glacial river and lake have changed in many ways in the following decades, which could mean that there is now a much larger percentage which passes through the lake. This could partially explain why the results from the sediment station showed greater sediment transport than the results from the delta and the lake sediment cores.

\section{The limiting number of sediment cores and their locations}

The relatively small amount of usable cores from the lake and variance between them with regards to varve thickness can also give misleading results. Sediment thicknesses had to be extrapolated from the 13 readable cores from the basin and the results from the delta measurements in order to estimate values for the areas in the lake without usable cores. The foreset, which is the steep transition between the delta topset and the lake bottomset was especially difficult to measure. The fact that most of these areas were closer to the delta foreset and would therefore have higher amounts of sedimentation would mean that small uncertainties could have a greater effect on the results. These areas occupy a considerable amount of the lake area and could contain more sediments than the extrapolated estimations show, which could also be a factor in the disagreement between the two results. The sediment cores taken from the delta have such a great amount of coarse material of varying sizes that they do not have varves and cannot be analysed for individual years, unlike cores from the lake which are purely suspended sediments which have settled. Therefore it is only possible to measure the total amount of material of all sizes deposited in the delta in one single year, and not the amount 
of suspended sediments. Since we only have one grain size distribution for each area of the delta which is applied for the whole 25-year period of the study, it is difficult to obtain accurate evidence of the specific variation of the amount of suspended sediments deposited for each individual year. These are important factors since most sedimentation of finegrained material occurs in the delta top and delta foreset, and these areas have a great deal of uncertainty.

\section{Sources of error: Sampling season length}

Another source of error in this project is the short length of the season in which the sediment monitoring station can be in operation due to climatic conditions. In the northern climate and relatively high altitude of Jostedøla, Norway, the winter comes quite early in the fall and stays late in the spring. The sediment monitoring station must be taken down in September or October when the temperatures begin to drop below the freezing point and snow starts to accumulate for two reasons, the threat of avalanches and ice runs can damage the equipment, and the amount of ice in the water makes sampling difficult and will not give accurate results. It cannot be set up again until June, when after a significant amount of the snow melts. Although most sediment transport occurs over the summer, these processes can cause a significant amount of sediment transport during the fall-spring period which is not registered by the ISCO, although this goes against the findings of our experiment where the values for sediment transport measured by the ISCO were actually too high.

\section{CONCLUSION}

The results show that sediment core analysis combined with delta measurements is a method accurate enough to give a good estimate of annual suspended sediment yields for individual years or periods of several years. In addition, sediment cores can be used to extrapolate results for suspended sediment load to fill in gaps and missing data in historical records of annual sediment transport. They can also give us information about the past, such as historical floods and climate changes. The results from sediment cores can be used to determine suspended sediment yield when there are unexpected factors which interfere with obtaining accurate results from sediment monitoring stations.

If we compare the whole 25-year period there seems to be a good relation between the two methods of estimating sediment transport. Difficulties in carrying out accurate water discharge measurements is probably the most important factor causing a discrepancy. On the other hand, the use of varves to estimate single years does not show such a great degree of correlation due to the yearto-year variation of hydrological conditions. In further studies investigations of the flow pattern through the lake could be compared to varve thickness to obtain a better idea of how sedimentation is affected by water currents in the lake.

Acknowledgements: This paper was funded by the NVE research program. Kjell Holmgren contributed by creating the computer program used to analyse the sediment cores and by helping to prepare and photograph them. 


\section{REFERENCES}

BOGEN J., 1983: Morphology and sedimentology of deltas in fjord and fjord valley lakes. Sedimentary Geology. 36, 245-267.

BOGEN J., 1986: Sampling of suspended sediments in streams. Particle - bound fluvial transport and soil erosion (Partikulært bundet stoftransport I vand og jorderosjon, ed. B. Hasholt). NHP rep. No 14, KOHYNO.

BOGEN J., 2006: Sediment transport rates of major floods in glacial and non-glacial rivers in Norway in the present and future climate. Pp 148- 158 in: J.S. Rowan, R.W. Duck, \& A. Werritty (eds). Sediment Dynamics and the Hydromorphology of Fluvial Systems. IAHS publication 306.

BOGEN J., BONSNES T.E., 2003: Erosion prediction in ungauged basins: Integrating methods and techniques (Proceedings of symposium HS01 Held during IUGG2003 at Sapporo, July 2003). IAHS Publ. No 279.

GILBERT R., GLEW J., 1985: A portable percussion coring device for lacustrine and marine sediments. Journal of Sedimentary Research. 55 (4), 607-608.

GILBERT R., CROOKSHANKS S., HODDER K.R., SPAGNOL J., STULL R.B., 2006: The record of an extreme flood in the sediments of montane Lillooet Lake, British Columbia: Implications for paleoenvironmental assessment. Journal of Paleolimnology. 35 (4).

GJESSING Y.T., WOLD B., 1980: Flommen I Jostedalen 14-15 August 1979, Varet 1.

GUSTAVSON T., 1972: Sedimentation and physical limnology in proglacial Malaspina Lake, Alaska. Technical Report no. 5-CRC. Coastal Research Center, University of Massachusetts.

OLSEN H.C., ZIEGLER T., 1987: Sedimentasjon, vannføring og materialtransport i Nigardsvatn (Sedimentation, water discharge and material transport in Nigardsvatn). Glasiologiske undersøkelser i Norge 1984. NVE publication nr. 7 (with an English summary), 46-54.

OLSEN H.C., 2008: Nye undersøkelser av sedimenttransport fra Nigardsbreen i perioden 1980-2006 på grunnlag av analyser av vannets bunnsedimenter (New studies of sediment transport from Nigardsbreen glacier in the period 1980-2006 on the basis of analyses of the sediments from the lake bottom). Internal NVE report in Norwegian.

REASONER M.A., 1993: Equipment and procedure improvements for a lightweight, inexpensive, percussion core sampling system. Journal of Paleolimnology. 8 (3).

ØSTREM G., HAAKENSEN N., OLSEN H.C., 2005. Sediment transport, delta growth and sedimentation in Lake Nigardsvatn, Norway. Geogr. Ann., 87A (1), 243-258.

ZOLITSCHKA B., 1997: A 14,000 year sediment yield record from western Germany based on annually laminated lake sediments. Geomorphology 22 (1998), 1-17.

Streszczenie: Oszacowanie dlugookresowej dostawy rumowiska na podstawie analizy rdzeniowej. W pracy przedstawiono wyniki badań prowadzonych według dwóch różnych metod pomiaru ilości rumowiska unoszonego, dostarczonego w latach 1980-2005 do jeziora Nigardsvatn w Norwegii, które zasilane jest wodami roztopowymi z lodowca Jostedalsbreen. Wielkość dostawy rumowiska, określoną na podstawie analizy rdzeniowej z sondowania geologicznego osadów dennych jeziora, porównano z wynikami uzyskanymi na podstawie danych z 25-cio letniego ciąu pomiarów zmącenia $\mathrm{w}$ rzece zasilającej jezioro. Stwierdzono, że różnica w wielkości dostawy rumowiska do jeziora określona dwiema metodami wynosi 4-20\%, przy czym mniejsze wartości uzyskano na podstawie analizy rdzeniowej osadów. Autorzy uważaja, że metoda ta może być stosowana do oszacowania lub korygowania wyników pomiarów zmącenia w rzekach zasilających jeziora i zbiorniki wodne w dostatecznie długich okresach.

\section{MS. received April 2010}

Authors' address:

Norwegian Water Resources and Energy

Directorate

P.O. Box 5091, 0301 Oslo

Norway

e-mailpadk@nve.no 